\title{
DAMPAK INFLASI PADA PINJAMAN (QARD) \\ DALAM HUKUM PERNIAGAAN ISLAMI
}

\author{
Desi Wahyuni \\ UIN Sunan Kalijaga Yogyakarta \\ desiwahyuni152@gmail.com
}

\begin{tabular}{l|l|l} 
Diterima: Maret 2019 & Direvisi : Mei 2019 & Diterbitkan: Juni 2019 \\
\hline
\end{tabular}

\begin{abstract}
The occurrence of inflation in the modern era is used by creditors to request the additional loans given to debtors. In Islamic economics, loans must be repaid without the determination of the index of commodities, currencies, or any group of currencies. However, someone can lend it in the form of gold or other currencies according to the perception of people who are not vulnerable to inflation. Inflation control in Islamic commercial law must be in accordance with mu'amalah validity by using instruments that avoid gharar, usury, qimar and maisir (game of opportunity), and two contracts (contracts) that are interdependent and free mutual agreement, contractual compliance (contract) with maqasid syariah, profits with obligations, are permitted as general rules.
\end{abstract}

Keywords: Inflation, Loans, Islamic Commerce

\begin{abstract}
Abstrak: Terjadinya inflasi pada era modern ini dimanfaatkan oleh para kreditur untuk meminta tambahan atas pinjaman yang diberikan untuk debitur. Dalam ekonomi islam, pinjaman harus dilunasi tanpa adanya ketetapan akan pengenaan indeks dengan komoditas, valuta, atau sekelompok valuta apapun. Namun, seseorang dapat meminjamkan dalam bentuk emas atau valuta lain yang menurut presepsi orang tidaklah rentan terhadap inflasi. Pengendalian inflasi dalam bukum perniagaan islam haruslab sesuai dengan validas mu'amalah dengan menggunakan instrumen yang terbindar dari
\end{abstract}


gharar, riba, qimar dan maisir (permainan peluang), dan dua kontrak (akad) yang saling bergantung serta adanya persetujuan bersama yang bebas, kesesuaian kontrak (akad) dengan maqasid syariah, keuntungan dengan kewajiban, diperbolebkan sebagai peraturan umum.

Kata Kunci: Inflasi, Pinjaman, Perniagaan Islam

\section{A. LATAR BELAKANG}

Inflasi dalam ekonomi modern sangat memberatkan masyarakat. Dimana adanya inflasi mengakibatkan kenaikan harga komoditas secara terus menerus, serta membuat nilai uang dan komoditas lain menjadi menurun. Hal tersebut menjadi sorotan dalam sistem ekonomi Islam. ${ }^{1}$

Dalam sistem ekonomi Islam, inflasi disebabkan oleh Natural Inflatio, seperti uang yang masuk dari luar negeri terlalu banyak karena terjadinya paceklik, perang, ataupun embargo dan boycott. Kemudian Human Error Inflation yang disebabkan oleh kesalahankesalahan dari manusia seperti korupsi, administrasi yang buruk dan pajak yang tinggi sehingga memberatkan pihak-pihak tertentu. ${ }^{2}$

Suatu sistem ekonomi memiliki strategi tersendiri, termasuk kebijakan dalam menekan inflasi. Adapun strategi tersebut seperti: pertama, perbaikan moral, di mana seseorang diajarkan bukan hanya untuk mencari materi namun juga diajarkan untuk menanamkan nilai spiritual. Kedua, adanya pendistribusian pendapatan dan kekayaan yang merata. Ketiga, penghapusan riba. Sebab elemen paling penting untuk merealisasikan tujuan-tujuan Islam adalah bersatunya semua hal yang dianggap sebagai aspek kehidupan dengan spirit untuk meningkatkan moral manusia dan masyarakat tempat bersosialisasi. Tanpa peningkatan spirit semacam ini, tidak akan ada satu tujuanpun yang dapat direalisasikan dan kesejahteraan manusia yang sesungguhnya menjadi sulit untuk diwujudkan. ${ }^{3}$

2009), h. 221

1 P. Eko Prasetyo, Fundamental Makroekonomi, (Yogyakarta: Beta Offset,

${ }^{2}$ Afzalur Rahman, Doktrin Ekonomi Islam, terj Soerojo dan Nastangin, Jilid I, (Yogyakarta: Dana Bhakti Wakaf, 1999), h. 10.

${ }^{3}$ M. Umar Chapra, Al-qur'an Menuju Sistem Moneter Yang Adil, Terj. Lukman Hakim, (Yogyakarta: Dana Bhakti Prima Yasa, 1997), h. 16. 
Ketika terjadinya suatu inflasi, banyak oknum-oknum tertentu yang menebar jaring untuk mencari keuntungan. Terjadinya inflasi pada era modern ini dimanfaatkan oleh para kreditur untuk meminta tambahan atas pinjaman yang diberikan untuk debitur. Kelemahan debitur ketika terjadinya inflasi adalah membuat mereka merasa tercekik atas pinjaman yang diterimanya. Hal tersebut dikarenakan adanya; 1) penetapan keuntungan di awal 2) tambahan atas nilai pokok yang berlipat 3) pembebanan risiko dan kerugian kepada peminjam 4) penzhaliman dan 5) motif ingin selalu untung. ${ }^{4}$

Pengendalian inflasi dalam hukum perniagaan islam haruslah sesuai dengan validas mu'amalah dengan menggunakan instrumen yang terhindar dari gharar, riba, qimar dan maisir (permainan peluang), dan dua kontrak (akad) yang saling bergantung serta adanya persetujuan bersama yang bebas, kesesuaian kontrak (akad) dengan maqasid syariah, keuntungan dengan kewajiban, diperbolehkan sebagai peraturan umum.

Penelitian ini merupakan penelitian kualitatif dengan menggunakan metode deskriptif-analisis. Dalam penelitian ini penulis akan menganalisis dampak inflasi pada pinjaman sesuai dengan hukum perniagaan Islami. Sehingga mampu menggambarkan solusi mengenai kontrak (akad) sebuah pinjaman ketika menghadapi inflasi sesuai dengan validitas mu'amalah.

\section{B. PEMBAHASAN}

\section{HAKIKAT PINJAMAN (QARD)}

\section{a. Definisi Pinjaman (Qard)}

Secara etimologi Qard adalah "memotong". Ia disebut demikian karena barang dipotong dari kepemilikan yang memberi pinjaman ketika barang tersebut dipinjamkan kepeminjam. ${ }^{5}$ Harta yang dibayarkan kepada muqtarid (orang yang diajak akad qard) dinamakan qarad, sebab merupakan

${ }^{4}$ Kamil Musa, Al-Abkam al-Mu"amalat, (Beirut : Muassasah ar-Risalah, 1998) h. 354

${ }^{5}$ Muhammad Ayyub, Understanding Islamic financing...., h.242 
potongan dari harta muqrid (pemilik barang). ${ }^{6}$ secara hukum, Qard berarti memberikan apapun yang bernilai kepada yang lain sehingga secara kedemarmawanan pihak kedua dapat menikmati manfaat yang sama dengan syarat jumlah yang sama atau serupa dengan barang tersebut harus dibayarkan kembali ketika diminta pada waktu yang telah ditentukan. ${ }^{7}$

Dalam literatur lain, Qard adalah pemberian harta kepada orang lain yang dapat ditagih atau diminta kembali atau dengan kata lain meminjamkan tanpa mengharapkan imbalan. ${ }^{8}$

Qardh merupakan pinjaman kebajikan/lunak tanpa imbalan, biasanya untuk pembelian barang-barang fungible (yaitu barang yang dapat diperkirakan dan diganti sesuai berat, ukuran, dan jumlahnya). Kata qardh ini kemudian diadopsi menjadi credo (romawi), credit (Inggris), dan kredit (Indonesia). Objek dari pinjaman qardh biasanya adalah uang atau alat tukar lainnya yang merupakan transaksi pinjaman murni tanpa bunga ketika peminjam mendapatkan uang tunai dari pemilik dana (dalam hal ini bank) dan hanya wajib mengembalikan pokok pinjaman pada waktu tertentu di masa yang akan datang. Peminjam atas prakarsa sendiri dapat mengembalikan lebih besar sebagai ucapan terima kasih. ${ }^{9}$

Dari pengertian diatas, maka esensi yang dapat diambil adalah bahwa sesungguhnya pinjaman-pipinjaman merupakan suatu bentuk mu'amalah yang bercorak ta'awun (pertolongan) kepada pihak lain untuk memenuhi kebutuhannya. Dalam menjalani kehidupan yang bermasyarakat, manusia diperbolehkan untuk melakukan bentuk kerjasama dalam bentuk apapun. Akan tetapi,

6 Azharuddin Lathif, Figh Muamalat, (Jakarta: UIN Jakarta Press, 2005), Cet.1, hlm. 150

${ }^{7}$ Ibid.., h.242., baca juga Sayyid Sabiq, fiqh al Sunnah, Juz 12, (Al-kuwait: Dar Al Bayan, tt), h.166

${ }^{8}$ Heri Sudarsono, Bank dan Lembaga Keuangan Syari'ah Deskripsi dan Ilustrasi, Edisi 2, (Yogyakarta: Ekonisia, 2003), h. 70. 2014), h. 46

9 Ascarya, Akad dan Produk Bank Syariah, (Jakarta: Raja Grafindo Persada, 
kerjasama tersebut diharapkan dapat memberikan manfaat baik untuk diri sendiri maupun untuk masyarakat sehingga tidak terjadi kedzaliman bagi para pihak yang berkerjasama.

Selama empat belas abad, umat islam telah sepakat bahwa pinjaman adalah salah satu bentuk muamalah yang dilegalkan oleh syariat Islam. ${ }^{10}$ Hal tersebut merupakan sebuah implementasi tolong menolong dalam kebaikan dan takwa. ${ }^{11}$ Bahkan secara akal, manusia sangat membutuhkan kegiatan muamalah tersebut. Kelas kehidupan antara si kaya dan si miskin didunia adalah hal yang lumrah (sunnatullah). Ada kalanya si miskin sedang dalam kesempitan sehingga membutuhkan bantuan yang bisa melapangkan kesempitan tersebut. Salah satu hal yang bisa mengimplementasikan tugas kemanusiaan tersebut adalah dengan melegalkan pinjaman.

Pinjaman dapat berupa apapun yang memiliki nilai barang yang serupa atau penggantinya harus dibayarkan seketika atau dalam waktu yang telah ditentuka oleh yang memberikan pinjaman. Hakikat Qard adalah pertolongan dan kasih sayang bagi yang meminjam. Ia bukan sarana mencari keuntungan bagi yang meminjamkan, didalamnya tidak ada imbalan dan kelebihan pengembalian. Sebagaimana ketentuan dalam Pasal 1 angka 11 Peraturan Bank Indonesia Nomor 7/46/ PBI/2005 tentang Akad Penghimpunan dan Penyaluran Dana Bagi Bank yang Melaksanakan Kegiatan Usaha Berdasarkan Prinsip Syariah, diartikan Qardh, adalah pinjam meminjam dana tanpa imbalan dengan kewajiban pihak peminjam mengembalikan pokok pinjaman secara sekaligus atau cicilan dalam jangka waktu tertentu. ${ }^{12}$ Ia mengandung nilai kemanusiaan dan sosial yang penuh kasih sayang untuk memenuhi hajat peminjam.

10 Amir Syarifuddin, Garis-garis Besar Fiqh, (Jakarta: Prenada Media, Edisi Pertama, Cet. Ke-2, 2005), h. 223.

11 Arif Munandar Riswanto, Khasanah Buku Pintar Islam, Jakarta: Mizan Pustaka, 2010), h. 1

12 Farid Budiman, "Karakteristik Akad Pembiayaan Al-Qardh Sebagai Akad Tabarru", Yuridika, Vol. 28, No. 3, (2013) : 406-418 


\section{b. Dasar Hukum Pinjaman (Qard)}

Qardh (pinjam meminjam) hukumnya boleh dan dibenarkan secara syariat. Tidak ada perbedaan pendapat di antara para ulama dalam hal ini. Orang yang membutuhkan boleh menyatakan ingin meminjam. Ini bukan sesuatu yang buruk, bahkan orang yang akan dipinjami justru dianjurkan (mandub). ${ }^{13}$ Dalil mengenai hal ini terdapat dalam Al- Quran : surat Al-Baqarah ayat 245.

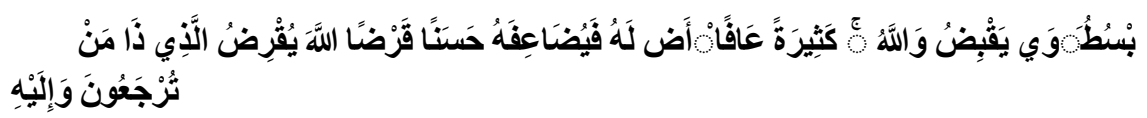

Artinya: siapakah yang mau memberi pinjaman kepada Allah, pinjaman yang baik (menafkahkan hartanya di jalan Allah), Maka Allah akan meperlipat gandakan pembayaran kepadanya dengan lipat ganda yang banyak. dan Allah menyempitkan dan melapangkan (rezki) dan kepadaNya-lah kamu dikembalikan.

Sebagaimana didalam QS.Al Maidah ayat 2 juga menerangkan :“ ... Hendaklah kamu tolong menolong dalam kebaikan dan takwa dan janganlah kamu tolong menolong untuk berbuat dosa dan permusuhan". Ayat ini menerangkan bahwa tolong menolong dalam ketaqwaan merupakan salah satu faktor penegak agama karena saling tolong menolong akan menciptakan rasa saling memiliki di antara umat sehingga akan lebih mengikat persaudaraan sebagai bagian dari kehidupan bermasayarakat (civil society). ${ }^{14}$

Dari Ibnu Mas'ud meriwayatkan bahwa Nabi Saw. Berkata, "Bukan seorang muslim (mereka) yang meminjamkan muslim (lainya) dua kali kecuali yang satunya adalah (senilai) sedekah" (HR Ibnu Majah no. 2421, kitab al-

${ }^{13}$ Musthafa Dib Al-Bugha, Fiqh Al-Mu'awadhah, diterjemahkan oleh Fakhri Ghafur dengan judul : Buku Pintar Transaksi Syariah, (Jakarta: Mizan Publika, 2010), h.52.

14 Abd.Shomad dan Trisadini P.Usanti, "Asas-Asas Perikatan Islam dalam Akad Pembiayaan”, Yuridika, Vol. 24, No.3 (2009): 214. 
Ahkam; Ibnu Hibban dan Baihaqi).

Berdasarkan hadis tersebut transaksi pinjam meminjam merupakan bukan usaha untuk pengembangan modal, akan tetapi hubungan bisnis dalam ajaran Islam haruslah didasari atas saling tolong menolong ${ }^{15}$ karena dalam setiap kegiatan usaha tidak selalu keuntungan yang akan diperoleh. Bahkan akan mengalami kerugian sehingga tidak menutup kemungkinan berhpinjaman untuk menutupi kerugiannya. Anas bin Malik berkata bahwa Rasulullah berkata, "Aku melihat pada waktu malam di-isra'-kan, pada pintu surga tertulis: sedekah dibalas sepuluh kali lipat dan Qard delapan belas kali. Aku bertanya, 'wahai jibril, mengapa qardh lebih utama dari sedekah?' ia menjawab, 'karena peminta-minta sesuatu dan ia punya, sedangkan yang meminjam tidak akan meminjam kecuali karena keperluan." (HR Ibnu Majah no.2422, kitab al-Ahkam, dan Baihaqi).

Para ulama telah menyepakati bahwa Qard boleh dilakukan. Kesepakatan ulama tersebut didasari pada tabiat manusia yang tidak bisa hidup tanpa pertolongan dan bantuan saudaranya. Tidak ada seorang pun yang memiliki segala barang yang dibutuhkan. ${ }^{16}$ Oleh karena itu, pinjammeminjam sudah menjadi satu bagian dari kehidupan di dunia. Islam adalah agama yang sangat memperhatikan segenap kebutuhan umatnya. ${ }^{17}$

Berdasakan urain diatas dapat dipahami bahwa, akad Qard merupakan salah satu transaksi non profit dimana karakteristik dari akad Qardh tersebut adalah akad tabarru' dimana pinjam meminjam yang menitikberatkan pada sikap tolong menolong atau ta'awun.

15 Syaikh Faishal bin Abdul Aziz Alu Mubarak, Ringkasan Nailul Authar, (Jakarta: Pustaka Azzam, 2012), hlm. 118

16 Imam Mustofa, Fiqh Mu'amalah Kontemporer, Jakarta: Rajawali Pers, 2016), h. 132-133

17 Muhammad Syafi'i Antonio, Bank Syariah: Dari Teori ke Praktik, (Jakarta: Gema Insani Press, 2001), hlm.132-133 


\section{c. Perbedaan Antara Pinjaman Uang Dan Pinjaman Barang}

Adanya perbedaan antara pinjaman yang berupa uang dengan pinjaman berupa barang. ${ }^{18}$ yakni pinjaman yang terjadi karena pinjam meminjam uang yang terjadi karena pengadaan barang. Pinjaman yang terjadi karena pinjam meminjam uang tidak boleh ada tambahan, kecuali dengan alasan yang pasti dan jelas, seperti biaya materai, biaya notaris dan study kelayakan. Untuk tambahan yang lainnya yang sifatnya tidak pasti dan tidak jelas, seperti inflasi dan deflasi, maka tidak diperbolehkan. ${ }^{19}$ Pinjaman yang terjadi karena pembiayaan pengadaan barang harus jelas dalam satu kesatuan yang utuh atau disebut harga jual. Harga jual itu sendiri terdiri atas harga pokok barang plus keuntungan yang disepakati. Sekali harga jual telah disepakati, selamanya tidak boleh berubah naik karena akan masuk dalam kategori riba fadl. Dalam transaksi perbankan syariah, yang muncul adalah kewajiban dalam bentuk pinjaman pengadaan barang, bukan pinjaman uang. ${ }^{20}$

\section{INFLASI DALAM TINJUAN EKONOMI ISLAM}

Inflasi merupakan suatu proses kenaikan harga-harga yang berlaku dalam suatu perekonomian. Sedangkan tingkat inflasi adalah presentasi kenaikan harga-harga barang dalam periode waktu tertentu. ${ }^{21}$ Ada tiga hal yang perlu ditekankan dalam memahami inflasi22, yaitu;

a. Adanya kecenderungan haraga-harga untuk meningkat.

b. Kenaikan harga tersebut terjadi secara terus-menerus (sustained).

18 Ahmad ifham sholihin, Buku Pintar Ekonomi Syariah, (Jakarta: Gramedia Pustaka Utama, 2013), h.167

${ }^{19}$ Muhammad Ayub, Understanding Islamic financing...., h.242

${ }^{20}$ Muhammad Syafi'i Antonio, Bank Syariah: Dari Teori ke Praktik, (Jakarta: Gema Insani Press, 2001), hlm.132-133

21 Sadono Sukirno, Makro Ekonomi Teori Pengantar, (Jakarta: Rajawali Pers, 2010), h. 45

22 Nawawi Marhaban, Ekonomi Islam; Perspektif Teori, Sistem, dan Aspek, (Surabaya: Putra Media Nusantara, 2009), h. 89. 
c. Tingkat harga yang dimaksud adalah tingkat harga umum, artinya bukan hanya satu komoditas saja. ${ }^{23}$

Dalam ekonomi islam, inflasi bukanlah sebuah permasalahan utama ekonomi secara agregat, dengan indikator penggunaan mata uang dinar dirham. Namun, penunurunan nilainya sangat mungkin terjadi, yaitu ketika nilai emas yang menjadi bahan dasar utama dinar mengalami penurunan. Tetapi, keadaan tersebut sangat kecil kemungkinannya terjadi. 24

Inflasi secara umum disebabkan oleh dua hal, yaitu tarikan permintaan (kelebihan likuiditas alat tukar) dan yang kedua adalah desakan produksi dan termasuk kurangnya distribusi. ${ }^{25}$ Untuk sebab yang pertama dipengaruhi oleh peran negara dalam kebijakan moneter, sedangkan untuk sebab kedua lebih dipengaruhi oleh peran negara dalam kebijakan pemerintah seperi kebijakan (perpajakan, pungutan, insentif, dan disinsentif), pembangunan infrastruktur, regulasi, dll.

Dalam sistem ekonomi Islam, inflasi disebabkan oleh Natural Inflatio. Jenis inflasi tersebut disebabkan oleh faktor-faktor kejadian yang bersifat alamiah, seperti uang yang masuk dari luar negeri terlalu banyak karena terjadinya paceklik, perang, ataupun embargo dan boycott. Kemudian inflasi juga disebabkan oleh HumanError Inflation. Jenis inflasi tersebut disebabkan oleh kesalahan-kesalahan dari manusia seperti korupsi, administrasi yang buruk dan pajak yang tinggi sehingga memberatkan pihak-pihak tertentu. ${ }^{26}$ Adapun inflasi yang diakibatkan dari kesalahan manusia yang melanggar atau menyimpang dari aturan dan kaidah-kaidah syariah antara lain sebagai berikut;

a. Monopoli. Ketika terjadinya sebuah monopoli pada suatu komoditas atau barang tertentu akan mendorong pelaku

${ }^{23}$ M. Arif, Teori Makro Ekonomi Islam, (Bandung; Alfa Beta, 2010), h. 123

${ }^{24}$ Nurul Huda, Ekonomi Makro Islam: Pendekatan Teoritis, (Jakarta: Kencana, 2009), h. 189.

${ }^{25}$ Idris Parakkasi, "Inflasi Dalam Perspektif Islam”, Laa Maisyir, Vol. 3, No. 1, (2016): 41-58

${ }^{26}$ Afzalur Rahman, Doktrin Ekonomi Islam, terj Soerojo dan Nastangin, Jilid I, (Yogyakarta: Dana Bhakti Wakaf, 1999), h. 10. 
usaha (pedagang) untuk semena-mena dalam menetukan harga. ${ }^{27}$

b. Talaqqqi Rukhban yaitu pedagang kota mencegat pedagang dari desa/daerah sehingga mereka tidak mendapatkan harga yang wajar. Kesempatan ini digunakan oleh pedagang kota untuk semena-mena menentukan dan menaikkan harga. ${ }^{28}$

c. Penipuan (tadlis) Yaitu pedagang melakukan kecurangan dalam timbangan dan takaran sehingga bisa mempengaruhi tingkat harga. ${ }^{29}$

d. Perjudian (maisyir) Yaitu terkait dengan spekulasi transaksi yang tidak terakait dengan kegiatan sektor riil. ${ }^{30}$

e. Riba Merupakan penyebab utama terjadinya inflasi. Karena riba merupakan instrumen biaya yang akan ditambahkan yang terus menerus seiring pertambahan waktu yang secara pasti akan mendorong tingkat kenaikan harga. ${ }^{31}$

f. Najasy Adalah melakukan rekayasa terhadap permintaan (palsu) yang akan mempengaruhi tingkat permintaan yang berpengaruh terhadap kenaikan harga. ${ }^{32}$

Suatu sistem ekonomi memiliki strategi tersendiri, termasuk kebijakan dalam menekan inflasi. Adapun strategi tersebut seperti: pertama, perbaikan moral, di mana seseorang diajarkan bukan hanya untuk mencari materi namun juga diajarkan untuk menanamkan nilai spiritual. Kedua, adanya pendistribusian pendapatan dan kekayaan yang merata. Ketiga, penghapusan riba. Sebab elemen paling penting untuk merealisasikan tujuan-tujuan Islam adalah

27 Asril Sitompul, Praktek. Monopoli dan Persaingan Usaha Tidak Sehat (Tinjauan Terhadap Undang-Undang Nomor 5 Tahun 1999), (Jakarta: PT Citra Aditya Bakti, 1999), h. 25 h. 172

${ }_{28}$ Muhammad Ayub, Understanding Islamic financing: A-Z Keuangan Syariah.....,

29 Yasardin, Asas Kebebasan Berkontrak Syariah, Jakarta: Prenada Media, 2018), h. 65

${ }^{30}$ Muhammad Ayub, Understanding Islamic financing: A-Z Keuangan Syariah....., h. 97

${ }^{31}$ Ibid...., h. 90

${ }^{32}$ Musthafa Dieb al-Bugha, Muhyiddin Mistu, $\mathrm{Al}$ Wafi: Syarah Hadis Arba'in Imam an-Nawawi, (Jakarta: Qisthi Press, 2017), h. 301 
bersatunya semua hal yang dianggap sebagai aspek kehidupan dengan spirit untuk meningkatkan moral manusia dan masyarakat tempat bersosialisasi. Tanpa peningkatan spirit semacam ini, tidak akan ada satu tujuanpun yang dapat direalisasikan dan kesejahteraan manusia yang sesungguhnya menjadi sulit untuk diwujudkan. ${ }^{33}$

Menurut pakar ekonomi Islam, inflasi berakibat sangat buruk bagi perekonomian karena:

1) Menimbulkan gangguan terhadap fungsi uang, terutama terhadap fungsi tabungan, fungsi pembayaran di muka dan fungsi unit perhitungan. Akibat beban inflasi tersebut, orang harus melepaskan diri dari uang dan aset keuangan. Inflasi juga mengakibatkan terjadinya inflasi kembali (selffeeding inflation). ${ }^{34}$

2) Melemahkan semangat masyarakat untuk menabung (turunnya MPS).

3) Meningkatkan kecenderungan berbelanja, terutama untuk barang-barang non primer dan mewah(naiknya MPC).

4) Mengarahkan investasi kepada hal-hal yang produktif seperti penumpukan kekayaan berupa tanah, bangunan, logam mulia, dan mata uang asing serta mengorbankan investasi produktif seperti pertanian, industri, perdagangan dan transportasi.

Oleh sebab itu, inflasi harus segera diantisipasi, maka dalam Islam terdapat dua kebijakan yang dapat dilakukan yaitu sebagai berikut. 35

a) Kebijakan fiskal, yaitu kebijakan dalam penerimaan dan pengeluaran anggaran yang dapat membuat anggaran itu seimbang, defisit atau surplus. Dengan tujuan untuk menetapkan stabilitas ekonomi, tingkat

${ }^{33}$ M. Umar Chapra, Al-qur'an Menuju Sistem Moneter Yang Adil...., h. 16.

34 Awaluddin, "Inflasi Dalam Prespektif Islam (Analisis Terhadap Pemikiran Al-Maqrizi)", Jurnal Ilmiah Syari 'Ah, Vol. 16, No. 2, (2017): 186217

35 Abdul Hadi Ilman, Uang Suatu Kajian Kontemporer, Jakarta: Gema Insani Press, 2001), h. 59. 
pertumbuhan ekonomi yang tinggi dan pemerataan pendapatan, terwujudnya persamaan dan demokrasi sesuai dengan ketentuan Islam.

b) Kebijakan moneter, yaitu tindakan pemerintah atau bank sentral untuk mempengaruhi situasi makro yang dilaksanakan melalui pasar uang (proses penciptaan uang). Sebab dalam konsep ekonomi Islam uang adalah milik masyarakat (money is goods public). Barang siapa yang menyimpan(menimbun) uang bearti ia mengurangi jumlah uang yang beredar di pasar yang akan mengakibatkan tidak berjalannya perekonomian. Selain itu, tujuan kebijakan moneter adalah untuk menjaga dan memelihara stabilitas uang sehingga pertumbuhan ekonomi yang diharapkan dapat tercapai.

\section{a. Kesesuaian Kontrak (Akad) Dengan Maqasid Syariah}

Perintah syari'ah diarahkan menuju perwujudan beragam tujuan untuk kesejahteraan umat manusia. ${ }^{36}$ Tujuan syari'ah ditekankan dalam banyak teks al-Qur'an dan Sunnah. Kontrak (akad) atau transaksi apa pun menghalangi salah satu sasaran tersebut tidaklah sah dalam syari'ah. Cukup jelas bahwa hak dari sesama umat manusia harus dihargai dari sudut pandang semua transaksi. Hak-hak Allah swt. dalam syari'ah juga mengacu pada semua hal yang melibatkan manfaat masyarakat secara luas. Dalam hal ini, mereka sesuai dengan hak publik dalam peraturan modern. Karenanya, kontrak (akad) apa pun seharusnya tidak berlawanan dengan manfaat publik secara luas. ${ }^{37}$

36 Muhammad Sholahudin, World Revolution With Muhammad, (Sidoarjo: mashun, 2009), h. 46

${ }^{37}$ Muhammad Ayub, Understanding Islamic financing...., h.177 


\section{b. Keuntungan Dengan Kewajiban}

Prinsip ini menyatakan bahwa sesorang berhak mendapatkan keuntungan hanya jika ia menanggung resiko kerugian dalam bisnis. kelebihan yang melewti batas pokokyang dibayarkan kepada kreditur oleh debitur dilarang karena kreditur tidak mengandung resiko bisnis sedikitpun berkaitan dengan sejumlah uang yang dipinjamkannya. ${ }^{38}$

\section{c. Diperbolehkan Sebagai Peraturan Umum}

Semua yang tidak dilarang diperbolehkan. Prinsip diperbolehkan menegakkan kenyataan bahwa semua perjanjian dan kondisi yang ada didalamnya diperbolehkan selama tidak bertentangan dengan salah satu teks yang tertera secara eksplisit dalam al-qur'an assunnah. ${ }^{39}$

\section{DAMPAK INFLASI PADA PINJAMAN}

Dalam ekonomi islam, inflasi bukanlah sebuah permasalahan utama. Sebuah pinjaman harus dilunasi tanpa adanya ketetapan akan pengenaan indeks dengan komoditas, valuta, atau sekelompok valuta apapun. Namun, seseorang dapat meminjamkan dalam bentuk emas atau valuta lain yang menurut presepsi orang tidaklah rentan terhadap inflasi. Dalam hal tersebut, kewajiban hutang tidak akan bertambah karena adanya inflasi. 40

Ketika menjelaskan pesyaratan Qard menurut hanafi, aljazirah memberikan contoh yang menarik: pembelian secara kredit sebanyak 4 paun atas daging dengan harga qirsh 5 per paun (total jumlah yang harus dibayarkan adalah 20 qirsh). Jika pada saat pembayaran harga daging tersebut jatuh ke qirsh per paun, A masih tetap harus membayar 20 bukan 8 qirsh. ${ }^{41}$ Selain itu ibn qudama juga mengamati bahwa semua barang fungible harus dikembalikan dalam

\footnotetext{
${ }^{38}$ Muhammad Ayub, Understanding Islamic financing...., h.177

${ }^{39}$ Ibid.., h.177

${ }^{40}$ Ibid.., h. 275

${ }^{41}$ Ibid.., h. 272
} 
kuantitas yang sama ketika dipinjamkan, tanpa mempertimbangkan adanya apresiasi atau depresiasi. ${ }^{42}$

Berdasarkan hukum perniagaan Islam untuk debitur dan kreditur seharusnya dilaksanakan sesuai dengan prinsip-prinsip syariah. Hal tersebut sesuai dengan hukum perdagangan islami bahwa kewajiban utama debitur adalah melunasi pinjamannya dalam pemenuhan kontrak (akad) yang telah dibuatnya dengan kreditur. Sementara kreditur dianjurkan untuk bersikap toleran dan lunak dalam pelunasan pinjaman, debitur juga diperingatkan bahwa pinjamannya harus dilunasi dan kegagalan pembayaran akan mendatangkan konsekuensi yang serius di dunia dan di akhirat. Pemberi pinjaman atau penjual secara kredit dapat meminta jaminan untuk memastikan pelunasan pinjamannya jika debitur tidak mampu melunasi kewajibannya. Hal tersebut tentunya menjadi salah satu unsur validitas mu'amalah yang harus dipenuhi yaitu adanya persetujuan bersama yang bebas, kesesuaian kontrak (akad) dengan maqasid syariah, keuntungan dengan kewajiban, dan diperbolehkan sebagai peraturan umum. Sehingga tidak ada pihak yang dirugikan dan mengandung unsur dzalim.

Pinjaman merupakan suatu kegiatan muamalah, oleh karena itu setiap kegiatan muamalah diatur dalam validitas mu'amalah. Ketika terjadi suatu kontrak (akad) pinjaman dan mengandung halhal yang bertentangan dengan validtas mu'amalah maka transaksi tersebut tidak diperbolehkan. Sistem Islami menentang eksploitasi atau ketidakadilan dalam bentuk apapun. Sehingga apa yang tidak dilarang, diperbolehkan. Oleh sebab itu, semua kontrak (akad) dianggap sah kecuali melanggar kitab Suci Al-Qur'an atau as-sunnah yang bertentangan dengan tujuan syariah.

Pemberian pinjaman dalam islam adalah suatu tindakan bermurah hati (dermawan) dan pemberi pinjaman memberikan barang atau uang yang dipinjamkan kepada peminjam untuk periode waktu tertentu tanpa adanya imbalan. Jika nilai pinjamannya menurun dikarenakan inflasi, hal ini dapat disamakan bahwa

42 Ibn Qudama, Abu muhammad Abdullah bin Ahmad, Al-mughni, (Mesir: Darul Manar, 1367 H), h.325 dalam Muhammad Ayub, Understanding Islamic financing: A-Z Keuangan Syariah...., h.272 
pemberi pinjaman telah melakukan kebajikan yang lebih besar. Kitab suci Al-qur'an mendukung pemberian waktu lebih bagi para peminjam yang mengalami kesulitan atau menghadapi kesulitan finansial. Oleh karena itu, Fiqh Council dari OIC dengan tegas menyatakan pelarangan keras atas solusi yang umum atas pengenaan indeks dari sejumlah uang yang dipinjamkan untuk biaya hidup, tingkat suku bunga, dan sebagainya. Namun sesorang dapat meminjamkan dalam bentuk emas atau valuta lain yang tidak dianggap rentan terhadap inflasi. Dalam kasus yang sama pula, kewajiban pinjaman yang harus dibayar tidak dapat bertambah karenaa adanya inflasi.

Pertimbangan yang penting mengenai hal ini adalah bahwa ketika valuta terdepresiasi, nilainya menurun semuanya; tidaklah ada bedanya apakah sesorang meminjamkannnya atau menahannya untuk dirinya sendiri dalam bentuk yang likuid. Jika ia meminjamkannya mengenakan indeks atas emas, misalnya guna menghindari penurunan nilai, sepertinya ia menganggap mengambil manfaat dari pinjaman yang diberikan kepada debitur tersebut akan menutupi kekurangan jumlah uangnya yang disimpan dalam petinya akan kehilangan nilai. Pengambilan manfaat dari pinjaman menjadikannya kontrak (akad) tidak sesuai dengan syariah.

Islamic fiqh councildalam OIC dalam sesi kedelapannya (2127 juni 1993) memutuskan hal berikut yang berkenaan dengan dampak inflasi atas pinjaman;

"Debitur dan kreditur dapat menyepakati pada hari penyelesaian, tapi bukan sebelumnya atas pelunasan pinjaman dalam valuta selain yang telah ditentukan untuk pinjamannya, asalkan nilai pertukaran yang digunakan adalah yang tersedia pada hari penyelesaian. Demikian pula untuk pinjaman yang cicilannya jatuh tempo dalam valuta tertentu, pihak yang terlibat dapat menyepakati pada hari pelunasan cicilian kapan pun, agar berlaku efektif secara penuh dalam valuta yang berbeda pada nilai tukar yang terjadi pada tanggal pelunasannya.... kedua belah pihak terlibat dalam kontrak (akad), menyetujui pelunasan biaya atau gaji dalam valuta tertentu untuk dapat dilunasi dalam pembayaran tunggal atau dalam cicilan dengan beragam valuta atau dilawankan dengan sejumlah emas, 
pelunasannya juga dapat dilakukan sesuai kesepakatan. Pijaman yang kontrak (akad)nya dalam valuta tertentu seharusnya tidak ditanamkan pada debitur atas nilai tandingannya dalam emas dan valuta lain karena praktik demikian ini akan membuat debitur melunasi pinjamannya dalam pinjaman dan valuta lain seperti yang telah disetujui pelunasannya". 43

\section{KESIMPULAN}

Inflasi bukanlah sebuah permasalahan utama dalam ekonomi islam. Jika nilai pinjamannya menurun dikarenakan inflasi, maka sebuah pinjaman harus dilunasi tanpa adanya ketetapan akan pengenaan indeks dengan komoditas, valuta, atau sekelompok valuta apapun. Namun, seseorang dapat meminjamkan dalam bentuk emas atau valuta lain yang menurut presepsi orang tidaklah rentan terhadap inflasi. Akan tetapi, Jika ia meminjamkan uangnya dengan mengenakan indeks atas emas, misalnya guna menghindari penurunan nilai, sepertinya ia menganggap mengambil manfaat dari pinjaman yang diberikan kepada debitur tersebut akan menutupi kekurangan jumlah uangnya yang disimpan dalam petinya akan kehilangan nilai. Pengambilan manfaat dari pinjaman menjadikannya kontrak (akad) tidak sesuai dengan syariah.

Kitab suci Al-qur'an mendukung pemberian waktu lebih bagi para peminjam yang mengalami kesulitan atau menghadapi kesulitan finansial. Setiap kegiatan muamalah diatur dalam validitas mu'amalah. Ketika terjadi suatu kontrak (akad) pinjaman dan mengandung hal-hal yang bertentangan dengan validtas mu'amalah maka transaksi tersebut tidak diperbolehkan. Dan berdasarkan hukum perniagaan Islami, debitur dan kreditur seharusnya melaksanakan tugasnya sesuai dengan prinsip-prinsip syariah.

43 Council of the Islamic Fiqh Academy, Resolutions and Recommendations, (Jeddah, IRTI IBD, 2000), h.163 dalam Muhammad Ayub, Understanding Islamic financing: A-Z Keuangan Syariah...., h.273 


\section{DAFTAR PUSTAKA}

Abd.Shomad dan Trisadini P.Usanti, "Asas-Asas Perikatan Islam dalam Akad Pembiayaan", Yuridika, Vol. 24, No.3 (2009): 214.

Abdul Hadi Ilman, Uang Suatu Kajian Kontemporer, (Jakarta: Gema Insani Press, 2001), h. 59.

Afzalur Rahman, Doktrin Ekonomi Islam, terj Soerojo dan Nastangin, Jilid I, Yogyakarta: Dana Bhakti Wakaf, 1999.

Ahmad ifham sholihin, Buku Pintar Ekonomi Syariah, Jakarta: Gramedia Pustaka Utama, 2013.

Amir Syarifuddin, Garis-garis Besar Fiqh, Jakarta: Prenada Media, Edisi Pertama, Cet. Ke-2, 2005.

Arif Munandar Riswanto, Khasanah Buku Pintar Islam, Jakarta: Mizan Pustaka, 2010.

Ascarya, Akad dan Produk Bank Syariah, (Jakarta: Raja Grafindo Persada, 2014.

Asril Sitompul, Praktek Monopoli dan Persaingan Usaha Tidak Sehat (Tinjauan Terhadap Undang-Undang Nomor 5 Tahun 1999), Jakarta: PT Citra Aditya Bakti, 1999.

Awaluddin, "Inflasi Dalam Prespektif Islam (Analisis Terhadap Pemikiran Al-Maqrizi)”, Jurnal Ilmiah Syari'Ah, Vol. 16, No. 2, (2017): 186-217

Azharuddin Lathif, Fiqh Muamalat, Jakarta: UIN Jakarta Press, 2005.

Council of the Islamic Fiqh Academy, Resolutions and Recommendations, Jeddah, IRTI IBD, 2000.

Farid Budiman, "Karakteristik Akad Pembiayaan Al-Qardh Sebagai Akad Tabarru”, Yuridika, Vol. 28, No. 3, (2013) : 406-418

Heri Sudarsono, Bank dan Lembaga Keuangan Syari'ah Deskripsi dan Ilustrasi, Edisi 2, Yogyakarta: Ekonisia, 2003.

Ibn Qudama, Abu muhammad Abdullah bin Ahmad, Al-mughni, Mesir: Darul Manar, $1367 \mathrm{H}$ 
Desi Wahyuni Dampak Inflasi pada Pinjaman (Qard)......

Ibrahim Anis, et al., al-Mu'jam al-Wasith, Kairo: Darul Ma'arif, 1972.

Idris Parakkasi, "Inflasi Dalam Perspektif Islam", Laa Maisyir, Vol. 3, No. 1, (2016): 41-58

Imam Mustofa, Fiqh Mu'amalah Kontemporer, Jakarta: Rajawali Pers, 2016.

Kamil Musa, Al-Ahkam al-Mu"amalat, Beirut : Muassasah ar-Risalah, 1998.

M. Arif, Teori Makro Ekonomi Islam, Bandung; Alfa Beta, 2010.

M. Umar Chapra, Al-qur'an Menuju Sistem Moneter Yang Adil, Terj. Lukman Hakim, Yogyakarta: Dana Bhakti Prima Yasa, 1997.

Muhammad Syafi'i Antonio, Bank Syariah: Dari Teori ke Praktik, Jakarta: Gema Insani Press, 2001.

Musthafa Dib Al-Bugha, Fiqh Al-Mu'awadhah, diterjemahkan oleh Fakhri Ghafur dengan judul : Buku Pintar Transaksi Syariah, Jakarta: Mizan Publika, 2010.

Musthafa Dieb al-Bugha, Muhyiddin Mistu, Al-Wafi: Syarah Hadis Arba'in Imam an-Nawawi, Jakarta: Qisthi Press, 2017.

Nawawi Marhaban, Ekonomi Islam; Perspektif Teori, Sistem, dan Aspek, Surabaya: Putra Media Nusantara, 2009.

Nurul Huda, Ekonomi Makro Islam: Pendekatan Teoritis, Jakarta: Kencana, 2009.

P. Eko Prasetyo, Fundamental Makroekonomi, Yogyakarta: Beta Offset, 2009.

Sadono Sukirno, Makro Ekonomi Teori Pengantar, Jakarta: Rajawali Pers, 2010.

Sayyid Sabiq, fiqh al Sunnah, Juz 12, Al-kuwait: Dar Al Bayan, tt.

Syaikh Faishal bin Abdul Aziz Alu Mubarak, Ringkasan Nailul Authar, Jakarta: Pustaka Azzam, 2012.

Yasardin, Asas Kebebasan Berkontrak Syariah, Jakarta: Prenada Media, 2018. 